\title{
Sukupuolta ja seksuaalisuutta kuvaavien termien suhteisuudesta
}

Tuula Juvonen

\section{ABSTRAKTI}

Tässä artikkelissa tarkastelen sitä, millaisia termejä käyttäen Suomessa elävät inmiset kertovat kokemuksistaan sukupuoli- ja seksuaalisuusnormien rikkojina tai heidän liittolaisinaan. Tutkimusaineistona on ollut Työväen muistitietotoimikunnan vuonna 2018 keräämiä muistoja unohtumattomista hetkistä. Minua kiinnostaa erityisesti se, mitä aineistot kertovat sopivien termien puuttumisen, löytämisen ja luomisen merkityksestä mahdollisesti muutoksessa olevan identiteetin hyväksymiselle ja samaistumisen mahdollistavan yhteisön löytämiselle. Tarkastelen itsensä nimeämistä esimerkiksi sellaisilla aineistoissa esiintyvillä termeillä kuin aseksuaalisuus, queer, bi- ja panseksuaalisuus sekä muunsukupuolisuus. Lisäksi sivuan suhdemuotojen moninaistumista kuvaavia termejä.

Aineistossa näkyy se, kuinka 2010-luvulla määrittelemättömyyden rinnalle ovat nousseet uudet, sukupuolta ja seksuaalisuutta yhä monimutkaisemmin ja tarkemmin nimeävät luokittelut, joilla varsinkin nuoret hahmottavat omaa relaationaalisesti rakentuvaa kokemusmaailmaansa ja olemisensa tapaa. Näen termistön moninaistumisen osana laajempaa käynnissä olevaa kulttuurista muutosta, jossa aiemmat sukupuoli- ja seksuaali-identiteettejä koskevat binaariset luokittelut ovat lähteneet liikkeelle, mikä luo sekä mahdollisuuden että uudenlaisen tarpeen itsensä nimeämiselle osana sosiaalisia suhdeverkkoja.

\section{ABSTRACT}

In this article I scrutinize the terms that Finns use when narrating their experiences of challenging gender and sexual norms or being allies to those who do. The analyzed data consists of memories collected in 2018 by the Commission of Finnish Labour Tradition (one of the bodies with national responsibility to collect LGBTQIA+ history) about most memorable moments. I am interested in the ways in which the materials described the lack of suitable terms, the meanings of finding or inventing them, as well as accepting identities or finding communities which allow identification through the terms. I analyze self-naming when such terms as asexuality, queerness, bisexuality and pansexuality or non-binary (here as muunsukupuolisuus) were used. I also touch upon the increasingly various relationship terminology.

In the materials it is evident that during the 2010s the new classifications address multiple genders and sexualities in ever increasing precision. They are used especially by the younger generation that seeks to understand its relational experiences and ways of being. I see the diversification of terminology as a part of a wider cultural change, during which the former binary classifications of gender and sexuality are in flux. This creates both opportunities and demands for naming oneself as a part of new social networks. 
Erityisesti 2010-luvulla ihmisten arkikokemuksessa on alkanut näkyä se, miten sukupuolen ja seksuaalisuuden moninaisuutta kuvailevat nimitykset ovat lisääntyneet, niiden oikeaoppisuudesta käydään kiivasta kamppailua, ja termien oikeaan käyttöön haetaan ja tarjotaan opastusta (esim. Väisänen 2014). Erityisesti nuoret hahmottavat omaa kokemusmaailmaansa ja olemisensa tapaa uusilla, sukupuolta ja seksuaalisuutta yhä monimutkaisemmin ja tarkemmin määrittelevillä luokitteluilla (Clarke ym. 2018, 230-231; Hammack ym. 2018). Seksuaalisuutta koskevasta itserefleksiivisyydestä ja introspektiosta on muodostunut meille taksonominen tapa, kuten brittiläinen historioitsija Laura Doan on todennut (Doan 2013, 142): me kategorisoimme ja nimeämme seksuaalista haluamme ja kokemuksiamme yhä uusin tavoin.

Työväen muistitietotoimikunnan vuonna 2018 toteuttama Unohtumattomat hetket -muistitietokeruu osui siis aikaan, jolloin sukupuolen ja seksuaalisuuden määrittelyt ovat melkoisessa muutoksessa. Verkossa toteutetun keruun tarkoituksena oli yhtäältä kartoittaa sitä, millä tavoin vastaajat kertovat kokemuksistaan sukupuolen ja seksuaalisuuden moninaisuudesta tai niihin liittyvästä liittolaisuudesta ${ }^{1}$, ja toisaalta sitä, millaisia ajallisia muutoksia näissä kokemuksissa on tunnistettavissa.

Tässä keruuaineistoon pohjautuvassa tutkimuksessani tarkastelen puolestaan sitä, miten aineistossa näkyy kokemuksen nimeämisen sosiaalinen ja vuorovaikutuksellinen luonne. Ehdotan, Leena-Maija Rossin (2016 [2018]) tavoin, että queertutkimuksessa käytyjä keskusteluja

1 Liittolaisuus (engl. allyship) viittaa ilmiöön, jossa etuoikeutettuihin ryhmiin kuuluvat solmivat luottamukseen perustuvia suhteita marginalisoituihin ryhmiin ja tukevat omalta osaltaan johdonmukaisesti näiden pyrkimyksiä yhdenvertaisuuden saavuttamiseksi. Esim. heterot voivat olla lesbojen ja homojen liittolaisia lisääntymisoikeuteen liittyvissä kysymyksissä, tai lesbot ja homot transihmisten liittolaisia vaadittaessa oikeutta sukupuolen itsemäärittelyyn. nimeämisestä ja identiteeteistä voisi rikastaa ja syventää ottamalla niihin mukaan relationaalisuudesta käytyjä teoreettisia keskusteluja. Lisäksi osallistun keskusteluun sukupuolen ja seksuaalisuuden moninaisuudesta tarjoamalla tulkintoja sekä uusien termien merkityksellisyydestä oman subjektiuden konstituoimiselle että termien ja niillä nimettyjen identiteettien jatkuvasta muuttumisesta Suomessa.

Rajaan tässä artikkelissa muistitietokyselyn vastauksista aineistokseni vastaajan valitsemia itsemäärittelyjä ja nimeämiseen liittyvää muistelukerrontaa. Vaikka aineistoa voisi tarkastella myös esimerkiksi affektikokemuksen (Juvonen \& Kolehmainen 2018) tai kehollisuuden näkökulmasta (Kähkönen 2018), jäsentelen vastauksia tässä tarkastelemalla niissä kuvattuja kielellisen vuorovaikutuksen kokemuksia ja erilaisia nimeämiseen liittyviä aspekteja.

Nimeämisen tarkasteluun keskittyvä näkökulmavalinta liittyy myös omaan henkilöhistoriaani. Olen itse nimennyt itseni vuonna 1989 uudelleen heterosta lesboksi, ja täsmentänyt identifikaatiotani eri aikoina erilaisilla määreillä, kuten feministi, femme, queerfeministi, tai olen vältellyt määrittelyjä tyystin. Näen, että uudet mahdollisuudet itseni nimeämiseen tai siitä kieltäy tymiseen ovat tarjonneet minulle yhä uusia tapoja nähdä itseni ja omat mahdollisuuteni, ja minua kiinnostaa se, miten eri sukupolvet käsittelevät vastaavia kokemuksia nykyisin.

Artikkelissani esittelen ensin muistitietokerrontaan perustuvan tutkimusaineistoni erityispiirteitä, minkä jälkeen syvennän nimeämistä koskevaa queertutkimuksellista keskustelua relaationaalisen teoretisoinnin avulla. Metodologisten pohdintojen jälkeen siirryn analysoimaan aineistostani heteronormatiivisen hiljaisuuden seurauksia. Osuvien termien löytämisen tärkeyttä käsittelen aseksuaalisuuden osalta. Seuraavaksi kiinnitän huomiota rinnakkaisten termien käyttöön, käyttäen esimerkkeinä termejä queer, bi-, ja panseksuaalisuus. Uusien termien luomista kartoitan muunsukupuo- 
lisuuden ja suhdemuotojen osalta. Lopuksi pohdin vielä sitä, millaisesta yhteiskunnallisesta muutoksesta on kysymys silloin, kun binäärikategorioiden rinnalle on nousemassa muita tapoja tarkastella liikkeellä olevia sukupuolia ja seksuaalisuuksia.

\section{Muistitietoaineiston keruu verkkokyselyllä}

Aineiston keruun aikaan, vuonna 2018, yhä useammat ihmiset kertoivat aiempaa avomielisemmin henkilökohtaisista asioistaan esimerkiksi sosiaalisessa mediassa. Vaikka verkossa käydään vilkkaasti keskustelua myös sukupuolen ja seksuaalisuuden moninaisuudesta, meillä ei kuitenkaan ole takeita siitä, miltä osin tästä digitaalisesta keskustelusta jää jälkiä tuleville tutkijoille. Siksi näitä teemoja koskevaa pohdintaa ja muistelua on syytä tallettaa aika ajoin myös pysyviin arkistoihin (Juvonen 2014). Unohtumattomat hetket -muistitietokeruussa tavoitetut kokemukset sukupuolen ja seksuaalisuuden moninaisuuden kanssa elämisestä ja liittolaisuudesta arkistoitiin Työväen muistitietotoimikunnan kokoelmiin. Tämä on siinäkin mielessä perusteltua, että muistitietotoimikunnan kokoelmat ovat osa Työväen Arkiston kokoelmia, ja Työväen Arkistolla puolestaan on valtakunnallinen velvoite tallettaa myös lesbojen, homojen, bi- ja transihmisten historiaa.

Muistitietokyselyn keruu oli auki verkossa 1.6.-30.11.2018. Tietoa keruusta jaettiin ensisijaisesti Unohtumattomat hetket -Facebook-sivuston kautta, josta tietoa linkitettiin eri tahoille erityisesti Suomessa ensi kertaa järjestetyn sateenkaarihistoriakuukauden aikana (20.10-20.11.2018). Nämä molemmat kontekstit raamittivat keruun historian tallentamiseksi ja tekemiseksi. Keruuta ei markkinoitu ostetuilla mainoksilla, mutta siitä julkaistiin lyhyet uutiset Työväen sivistysliiton verkkosivuilla 6.9.2018 ja Demokraatti-lehdessä 13.9.2018, ja liittolaisia tavoiteltiin myös poliittisten nuorisojärjestöjen kautta. Keruun verkkosivuosoitteesta kertovaa mainoslippusta jaettiin lisäksi kasvokkain esimerkiksi Helsinki Pridessä ja Kokkola Pridessä kesällä 2018 sekä Tampereella Leimareissa. Vastaajajoukko muodostui itsevalikoituneeksi siten, että vapaaehtoiseen kyselyyn vastasivat ne, jotka tunsivat asian syystä tai toisesta itselleen tärkeäksi. On oleellista huomata, että itsevalikoitunut otos ei kerro mitään siitä, kuinka yleisiä tai levinneitä vastauksiin tallentuneet ilmiöt ovat. Verkkokyselyllä on silti mahdollista kartoittaa ilmiöiden moninaisuutta ja niihin liittyviä puhetapoja (Suominen 2016, 117, 128).

Osallistujat saivat verkkolomakkeessa vastattavakseen aluksi joukon taustatietokysymyksiä, joista yksi oli avoin kysymys "miten määrittelisit nykyisin sukupuolesi ja seksuaalisuutesi?”. Kysymys itsessään on hyvä esimerkki ajallemme ominaisista itserefleksiivisyyteen ohjaavista käytännöistä, joilla velvoitetaan ihmisiä tekemään tiliä itsestään muille ja pakotetaan heitä enemmän tai vähemmän hienovaraisesti identifioimaan itsensä suhteessa käytössään oleviin hankaliinkin määritelmiin (Herrera $2017,8,13)$. Valmiiden vastausvaihtoehtojen puuttuessa avovastauksissa käytettiin kaiken kaikkiaan 16 erilaista vastaajalähtöistä luonnehdintaa sukupuolesta. Seksuaalista suuntautumistaan osallistujat luonnehtivat yhteensä 22 erilaisella termillä tai niiden täsmennyksellä. Lisäksi pieni osa vastaajista jätti joko sukupuolensa tai seksuaalisuutensa nimeämättä, tai he ilmoittivat, että he eivät halua määritellä itseään.

Kyselytutkimusten kysymyksenasettelut antavat vastaajille aina pieniä, mutta tärkeitä vihjeitä siitä, millaisia vastauksia heiltä toivotaan (Juvonen 2002). Niinpä tämän avoimen kysymyksen muotoilu ("nykyisin") rakensi itsemäärittelylle lisäksi ajallisen ulottuvuuden ja tarjosi samalla tilaa kertoa sen muutoksista. On kuitenkin mahdollista, että kysymykseen sisäänrakennettu moninaisuus ja muutos olivat myös asioita, jotka eivät puhutelleet niinkään miesvastaajia, jotka naisia useammin kuvailevat identiteettinsä vakaaksi ja yksiselitteisiksi (Morandini ym. 2016, 3, 8-9; Hammack ym. 2018, 15). 
Lomakkeessa oli neljä varsinaista muistitietoa tallentavaa kysymystä, joilla haettiin sukupuolen ja seksuaalisen moninaisuuden kanssa elävien vastaajien ja heidän liittolaistensa henkilökohtaisia kokemuksia sekä nettimaailman ulkopuolelta että verkossa tapahtuvasta vuorovaikutuksesta. Keruussa kannustettiin muistelemaan unohtumattomia hetkiä, jolloin monet vastaajista kuvasivatkin niitä välähdyksenomaisia tilanteita, joissa he olivat saavuttaneet korostuneen tietoisuuden omasta kokemuksestaan (Kähkönen 2018, 144). Vastaajia pyydettiin mainitsemaan kuvailussaan ainakin seuraavat seikat: mitä tapahtui, milloin tapahtui, keitä tapahtumassa oli osallisina ja miltä tapahtuma vastaajasta tuolloin tuntui. ${ }^{2}$ On kuitenkin ilmeistä, että muistelluilla tapahtumilla on sekä tapahtumisensa aika että kertomisensa tai muistelun aika, ja molemmat niistä ovat ratkaisevia sille, miten asioita voidaan ja halutaan muistaa myöhemmin (Taavetti 2018, 82-85). Kokemusten ajallinen ankkuroiminen mahdollistaa silti joidenkin ilmiöiden esiintymisen ajoittamisen, vaikka niihin liittyvä kokemuksellisuuden tuntu itsessään olisi kertomisen aikaan jo muuttunut.

Muistitietokysely tutkimusaineiston keruumenetelmänä sopii siinä mielessä hyvin tähän aikaan, että myös muistitietotutkimus tutkimusmenetelmänä on nykyisin siirtynyt käsittelemään yleisten aiheiden sijaan paremminkin henkilökohtaisen elämänpiirin kysymyksiä ja yksilön kokemuksia

2 Keruukysymykset, joissa haettiin ajassa muuttuvaa henkilökohtaista ja yhteiskunnallista kokemusta, ja niihin vastaamiseen ohjeistaminen saivat kimmokkeensa Weststrate \& McLeanin (2010) laatimasta kyselystä, jonka tutkijat ystävällisesti tarjosivat käyttööni.

Esimerkiksi yhteiskunnallisia kokemuksia kartoittava kysymys esitettiin suomalaisessa keruussa näin: "Kuvaile jokin unohtumaton, joko omakohtaiseen elämääsi tai muuten laajemmin sukupuolen tai seksuaalisuuden moninaisuuden kanssa elämiseen vaikuttanut sosiaalinen, kulttuurinen tai historiallinen tapahtuma tai ajanjakso, joka on joko merkittävästi muovannut käsitystäsi omasta seksuaalisesta tai sukupuoli-identiteetistäsi tai on ratkaisevasti vaikuttanut liittolaisuuteesi suhteessa näihin vähemmistöihin." Muut kysymykset noudattelivat samankaltaisia muotoiluja.
(Ekrem 2016, 88). Kokemukset olivat kiinnostuksen kohteena myös tässä verkossa toteutetussa keruussa. Verkkokyselyyn vastaaminen jatkaa omalla tavallaan yksityisen kirjoittamisen genreä (Pöysä 2006, 229-231). Analogiseen arkistoon päätyvä verkkokysely asettuu yksityisen ja julkisen rajalle, samaan tapaan kuin julkisen digiverkon syövereihin arkistoituva kokemuskirjoittaminen (Järvinen-Tassopoulos 2011, 204-205). Vastauksista päätellen tämä on monille osallistujille tuttu kirjoittamisen lajityyppi.

Koska muistitietokyselyn vastaukset talletettiin pysyvästi arkistoon laajemman tutkijajoukon käytettäviksi, vastaajille tarjottiin mahdollisuutta vastata kyselyyn anonyymisti. Lisäksi osallistujat saivat itse määritellä sen, vaatiiko vastauksen lainaaminen tutkimuksessa heidän mielestään lisää anonymisointia, vai katsoivatko he, että valittu kerronnan tapa jo itsessään suojeli riittävällä tavalla vastaajien ja vastauksissa esiintyvien henkilöiden yksityisyyttä.

Kyselyyn vastasi kaiken kaikkiaan 72 henkilöä, kaksi heistä sähköpostitse tai kirjeitse. Nettikyselyille tyypillisesti monet vastauksista olivat vaillinaisia (Suominen 2016, 135; Jones \& Brewster 2017, 682). Esimerkiksi vain 19 vastaajaa vastasi taustatietojen lisäksi kaikkiin neljään kysymykseen. Nettikyselyihin osallistuu usein myös satunnaisia vastaajia, joiden vastaukset ovat tyypillisesti varsin lyhyitä ja ylimalkaisia raportteja, joista ei voi juurikaan tehdä johtopäätöksiä vastaajan muusta elämänkokonaisuudesta (Ekrem 2016, 83, 86) tai hänen intersektionaalisista suhteisuuksistaan (Rossi 2016 [2008]). Lyhimmillään vastaus saattoi kaikkinensa olla vain yhden rivin mittainen. Poikkeuksen lyhyehköistä vastauksista muodostivat keruuta tukeneisiin yhteisöllisiin kirjoituskahviloihin osallistuneet kirjoittajat, joiden perinpohjaiset selvitykset ylsivät enimmillään noin 1650 sanaan.

Muistoja saatiin sekä heiltä, jotka eivät itse asettuneet yksiselitteisesti heteroseksuaalisuuteen tai cissukupuoleen että heidän ystäviltään ja liittolai- 
siltaan. Osallistujat olivat syntyneet vuosina 1941-2002 mediaanivuoden ollessa 1986, joskin merkittävä osa vastaajista oli syntynyt vasta 1990- ja 2000-luvuilla (30 henkeä). Maantieteellisesti he sijaitsivat pääsääntöisesti suurkaupungeissa (42), mutta muuten yhtä hyvin myös keskisuurissa (13) ja pienissä (8) kaupungeissa tai maaseudulla (7). Yksi vastaajista asui ulkomailla. Vastaukset viittasivat kuitenkin vahvasti siihen, että netin käyttäminen vähentää asuinpaikan merkitystä, sillä vastaajat olivat luoneet ja ylläpitäneet tärkeitä ystävyyssuhteita ja yhteisöjä asuinpaikastaan riippumatta myös verkossa.

Vastaajista suurin osa oli seksuaalisuuttaan eri tavoin määritteleviä (cis) naisia, mutta cismiehiä edusti vain kaksi homoa. Heteromiesten ja transfeminiinisten henkilöiden vastaukset jäivät puuttumaan kokonaan. Siinä missä sukupuolen ja seksuaalisuuden moninaisuuteen painottuva kysely joko tavoitti tai puhutteli erityisen huonosti cismiehiä, transmiehiä joukossa oli useampia.

\section{Itsensä nimeämisen suhteisuus}

Nimetyksi tuleminen on, kuten Judith Butler on todennut, väistämätöntä tunnustetuksi subjektiksi tulemiselle, sillä nimeäminen tuottaa subjektin ääriviivat tilassa ja ajassa (Butler 1997, 33-34). Tuija Pulkkisen mukaan itsensä nimeämisellä asetutaan jo kertaalleen kerrottuun kertomukseen ja tuotetaan näin sosiaalisesti tunnustettuja identiteettejä (Pulkkinen 1998, 180, 186). Sopivan nimityksen löytämiseen liittyy vahva tunne oikeasta minästä, ja se antaa oikeuden elää tunnustetusti myös erilaista elämää (mt., 190, 204). Nimeäminen voi tuntua väärältä silloin, kun käytössä olevat termit eivät riitä kuvaamaan omaa kokemusta, ja nimetyksi tuleminen voi tuntua myös nimitellyksi tulemiselta silloin, kun termejä käytetään loukkaamistarkoituksessa ja osana vihapuhetta (Butler 1997, 4-5). Jos subjektiksi tulemisen alistavuudesta kertoo nimetyksi ja nimitellyksi tuleminen, itsensä nimeäminen puolestaan kertoo siitä, miten tärkeää kokemuksellisesti oikein nimetyksi tuleminen on niin identiteetin kuin toimijuudenkin tunteen syntymiselle.

Ajatus oikein nimetyksi tulemisesta näkyi 1990-luvun lesbokirjallisuudessa autenttisen minän etsimisenä (Kosonen 1996, 186). Itse tulkitsen autenttisen minän etsimisen heijastaneen sitä todellisuutta, jossa vallitsevasti tarjolla olleet sukupuolen ja seksuaalisuuden heteronormatiiviset mallit eivät olleet riittäviä kuvaamaan vallitsevista odotuksista poikkeavien, sukupuoleltaan ja seksuaalisuudeltaan moninaisten ihmisten kokemusta. Tämä tuotti kalvavaa tunnetta epäautenttisuudesta, jota lesbojen autenttista identiteettikokemusta korostava omaelämäkerrallinen kirjoittaminen pyrki tahollaan ratkomaan (Kaskisaari 1995, 10-11). Sama teema toistui myös ajan lesbo- ja queertutkimuskeskusteluissa - ja kriittisimmillään itse autenttisuuden ajatuksen kyseenalaistamisessa suhteessa kokemuksellisuuteen ylipäänsä (Saresma 2010, 62-63).

Autenttisuuden ajatus liittyy moderniin seksuaalisuuskäsitykseen ja erityisesti seksuaalisuudesta tietämisen psykoseksuaaliseen sisäisyyteen. Silloin kun seksuaalisuuden ajatellaan olevan merkittävä osa persoonallisuuttamme ja identiteettiämme, tiettyjen seksuaalisten käytäntöjen harjoittajat nimetään tekojensa mukaisiksi henkilöiksi (Doan 2013, 143). Tällaiset sisäsyntyisyyteen nojaavat kategoriset identiteettimäärittelyt käsitetään helposti olemuksellisiksi ja siten vakaiksi, ja niihin kiinnitetään normatiivisia oletuksia. Tällaista identiteettinäkemystä queertutkimuksessa on lähdetty purkamaan (Rossi 2016 [2008).

Vaikka queertutkijat eivät sinänsä kiellä identiteettien olemassaoloa ja tarpeellisuutta ihmisten minäkäsitykselle, esimerkiksi Judith Butler on halunnut kyseenalaistaa ajatuksen identiteettien perustalähtöisestä autenttisuudesta (2006 [1990]). Jos ajattelemme Butlerin tavoin, että subjektit muodostuvat vasta tekojensa kautta, yksilön vahvakaan kokemuksellinen 
tunne oman nimensä löytäneen identiteetin autenttisuudesta ei itsessään ole todiste kokemuksen sisäsyntyisyydestä ja aitoudesta. Sen sijaan se herättää kysymyksen siitä, miten tällainen kokemus autenttisuudesta rakentuu.

Relaationaalisuuden tutkijat lähestyvät kokemuksen rakentumisen kysymystä toteamalla, että yksilö on väistämättä aina huokoinen. Me kaikki olemme lähtökohtaisesti aina affektiivisessa vuorovaikutuksessa muihin ihmisiin ja ympäristöömme, ja tämä molempiin suuntiin vaikuttava suhteisuus muokkaa niin meitä kuin kokemuksiammekin (Roseneil \& Ketokivi 2016). Nekin nimetyt identiteettikokemukset, jotka miellämme sisäisiksi ja henkilökohtaisiksi, ovat siten kulttuurisesti ja historiallisesti jaettuja, ja mahdollisia vain tietyssä ajassa.

Itsensä nimeäminen ja itsensä kertominen olivat teemoja, joita 1990-luvulla tutkittiin lesbo- ja homotutkimuksen kentällä kiivaasti. Onkin kiinnostavaa huomata, miten nämä teemat ovat nousseet uudestaan keskiöön. Kuten 2010-luvulla julkaistut haastattelukirjat ja tutkimukset (Holma ym. 2018; Ristikari ym. 2018; Taavetti 2015; Paasonen \& Spišák 2018) osoittavat, on tuskin sattumaa, että kiinnostuksen herääminen tapahtuu samaan aikaan, kun seksuaalisuuden nimeämisen taksonominen tapa on laajentunut koskemaan myös sukupuolta.

Näen myös, että seksuaalisuuden ja nyttemmin myös sukupuolen vakauden problematisoituminen on osin sen ansiota, että queerteorian avaamat pohdinnat ovat siirtyneet osaksi yhä useampien ihmisten tapaa hahmottaa omaa olemistaan. Esimerkiksi Eve Kosofsky Sedgwickin (1990) kaltaisten tutkijoiden dekonstruktiivinen tapa kyseenalaistaa binaareihin nojaavia ajattelumuotoja on tehnyt tilaa myös binaariluokitteluja haastavien sukupuolikäytäntöjen ja -kokemusten nimeämiselle. Samalla kun Butler on osoittanut, kuinka olemassa olevat nimitykset ohjaavat meitä normatiivisten sukupuolen ja seksuaalisuuden käytäntöjen toistamiseen, hän on myös nostanut esiin mahdollisuuden niiden toisintoistamiseen (Butler 2006 [1990]). Tämänkaltaiset pohdinnat ruumiillistuvat nyt ihmisten arjessa, jossa ne kaipaavat nimetyksi ja siten tunnustetuksi tulemista.

\section{Sopivien termien puuttuminen}

Kertomukset itselle sopivien sanojen ja termien puuttumisesta toistuivat eri tavoin muistitietokeruussa. Vastaajat kokivat ongelmalliseksi vahvan ja vaihtoehdottoman kulttuurisen oletuksen heteroseksuaalisuudesta, joka on estänyt heitä tunnistamasta sille vaihtoehtoja: "Olen aina sopeutunut huonosti heterokulttuuriin ja miesten ylivaltaan, ja suhteeni miesten kanssa olivat aina niin emotionaalisesti kuin seksuaalisesti laimeita, vaikka itse aikoinaan kuvittelin, että sellaista se nyt vain on (UH 5)." Heterosuhteita haastavien vuorovaikutussuhteiden puuttuminen vaikeutti tälle miehen kanssa naimisissa olevalle naiskertojalle oman epämukavuutensa nimeämistä ja haastamista. Mutta kuten tarjolla oleva haastatteluihin perustuva kokemuskirjallisuus (Holma ym. 2018) osoittaa, heterokulttuurin lisäksi myös cissukupuolisuutta kyseenalaistamattomana norminaan pitävä lesbokulttuuri voi toimia sellaisena tukevana yhteisönä, jonka sisäinen vuorovaikutus ja sinänsä myönteiseksi koetut affektiiviset siteet itseasiassa vain pitkittävät muunlaisen identiteetin hahmottamista:

Muutin Helsinkiin, enkä enää ajatellut olevani transihminen, identi-

fioiduin enemmän lesboksi. Mulla oli ihan selkeä mielenkiinto, olin kiinnostunut naisista. Se lesbolokero oli paljon yksinkertaisempi. Siinä yhteisössä, missä kaksikymppisenä olin mukana, oli tilaa sille, ettei ollut naisellisen näköinen nainen. Sai olla sen näköinen kuin oli (Leo, sit. Holma ym. 2018, 144).

Muun- ja transsukupuolisten vastaajien kuvailema kokemus sopivien termien puuttumisesta tai löytämisen vaikeudesta asettuu jännitteiseen 
suhteeseen ciskokemuksen kanssa, jota leimaa niin vahva itsestäänselvyys, että sitä ei muistitietovastauksissa usein edes erikseen nimetä. Kiinnostavasti kyllä, kuitenkin erityisesti ne vastaajat, jotka liikkuvat transihmisten kanssa yhteisissä tiloissa, nimeävät itsensä usein jo paitsi naisiksi, myös cisnaisiksi. Suhteiden solmiminen transihmisiin oli tältä osin muokannut näiden naisten itseymmärrystä.

Jotkut itsensä heteroiksi nimeävät vastaajat toivat kyselyn innoittamina itserefleksiivisesti esiin oman heteroutensa itsestäänselvyyden - he kertoivat sen olleen heidän kokemuksensa "aina", eikä heidän ollut tarvinnut pohtia tai kyseenalaistaa sitä missään vaiheessa (UH 10; UH 12; UH 28; Rosenberg 2017, 4). Jotkut vastaajista ovat aikuisiällä kuitenkin tulleet myös tietoiseksi vallitsevasta hetero-oletuksesta ja siitä, että heidän ei ole koskaan tarvinnut erikseen kertoa omasta heteroseksuaalisuudestaan kenellekään (UH 12; UH 51; UH 63). Heillä tämä tietoisuus omasta etuoikeutetusta tilanteestaan oli syntynyt vuorovaikutuksessa lesbo- ja homokulttuuriin.

Lisäksi vastauksista kävi ilmi, että vielä nykypäivänäkin oman ei-heteroseksuaalisuuden tunnistaminen on ollut monille vastaajille yllättävän vaikeaa. Tämä selittyy ainakin osaksi kouluopetuksen asenteellisuudella ja puutteellisuudella, jota nuorten on ollut vaikea lähteä haastamaan (ks. Taavetti 2015, 83, 86, 133). Muistitietokyselyyn vastannut, vuonna 1999 syntynyt kirjoittaja kuvaa tilannetta omalla kohdallaan näin:

Olin koko elämäni ennen vuotta 2017 pitänyt itseäni täysin heterona, koska peruskoulussa meidät opetettiin heteronormatiivisesti ja opin, että tytöt pitävät vain pojista ja toisinpäin. [...] Lukiossa mieleni avartui ja sain lisää tietoa seksuaali- ja sukupuolivähemmistöistä netin ulkomaalaisilta keskustelupalstoilta (UH 7).
Se, että vastaaja kykeni laajentamaan internetin tarjoaman tekstuaalisuuden välityksellä suhteisuutensa piiriä yli sen, mitä kouluopetus kykeni hänelle tarjoamaan, avarsi ratkaisevasti hänen seksuaalista minäkäsitystään. Sukupuolen ja seksuaalisuuden moninaisuuden kanssa elävillä ihmisillä on lähihistoriallisestikin katsottuna ollut läheinen suhde internetin käyttöön (Herrera 2017, 4). Netti on yleistyttyään mahdollistanut tiedon ja yhteisöjen löytämisen sekä erilaiset anonyymit identiteettikokeilut (Taavetti 2015, 106-108; Cavalcante 2018, 5, 18). Juuri netti, ja siellä esimerkiksi Twitter, YouTuben videoblogit ja Tumblrin mikroblogit ovat olleet reittejä, joiden kautta monet muutkin vastaajat ovat onnistuneet löytämään itselleen tärkeitä ihmisiä, neuvoa ja tukea (UH 38; UH 56; UH 59; myös Jenzen 2017, 1633, 1637 ja Cavalcante 2018 6-9).

Verkosta löytyvän vertaisryhmän rooli tiedonhankinnassa korostuu erityisesti niissä tilanteissa, joissa keskustelukumppaneita olisi muuten todella vaikea löytää, kuten vaikkapa tämän intersukupuolisen vastaajan tapauksessa:

Vertaisteni kirjotukset omasta kehostaan ja sukupuolestaan ovat auttaneet minua hahmottamaan itseäni ja suhdettani erilaisiin sukupuolten luokituksiin. Se on tuntunut monin tavoin marginaalissa elävälle helpottavalta. (UH 20.)

Toisaalta netissä liikkuminen altistaa sukupuolen ja seksuaalisuuden moninaisuuden kanssa elävät ihmiset heteronormia puolustavalle vihapuheelle. Samoin se mahdollistaa juuttumisen sellaisiin alakulttuurisiin yhteisöihin, jotka voivat olla myös vahingollisia omalle hyvinvoinnille (Taavetti 2015, 109-110; Cavalcante 2018, 17). Se, millaisiin teksteihin netissä törmää, on usein arpapeliä ja tärkeäksi verkkotaidoksi nouseekin itsensä suojaaminen vahingoittavilta viesteiltä (Jenzen 2017, 1631, 1634-1635), mihin myös osa osallistujista kiinnitti vastauksissaan huomiota. 
On kuitenkin täysin mahdollista kuvitella tilanteita, joissa tiettyjä kokemuksia nimeävien termien puuttumista voidaan pitää myönteisenä asiana. Kuten yksi muistitietokyselyn heterovastaajista kirjoitti, 1960-luvulla naiset eivät välttämättä edes tienneet, että homoseksuaalisuutta oli olemassa. Näin ollen heille ei myöskään tullut mieleenkään syrjiä työkavereitaan, joiden homous valkeni heille vasta pitkälti jälkikäteen (UH 23). Vaikka hiljaisuus on omalla tavallaan tuottanut turvallista tilaa aikana, jolloin homoseksuaaliset teot ovat olleet rikollisia, homoseksuaalisten ihmisten omalle itseymmärrykselle sanaton hiljaisuus on kuitenkin voinut olla samaan aikaan tuhoisaa. Kun heillä ei ollut käytettävissään tietoa omaa elämäänsä koskevista ilmiöistä, ne näyttäytyivät vain vaiettuina tabuina tai stereotypioiden valossa oudoiksi vääristyneinä.

Juuri homoseksuaalisuuden osalta on huomattavissa, kuinka termistön luomisen ja vakiintumisen rinnalla julkisen keskustelun määrä on purkanut nimeämättömyyteen liittyviä näkymättömyyden ja tunnistamattomuuden ongelmia, jolloin mahdollisuudet itseymmärryksen lisääntymiseen ovat radikaalisti kasvaneet. Monipuolisen mediakuvaston luominen vahvistaa ajatusta siitä, että seksuaalisuuden ja sukupuolen moninaisuutta on olemassa, eikä siinä ole mitään vääää tai epänormaalia (Taavetti 2015, 111). Nykyisin homoseksuaalisuus onkin pitkälti lomittunut heteroseksuaalisuuden rinnalle osaksi median läpitunkemaa arkea (Juvonen 2015, 32-70). Sama viesti välittyy myös kyselyn vastauksissa. Vastaajille niin julkkisten ulostulot (UH 27; UH 40; UH 69) kuin kulttuurituotteiden kuvastotkin ovat 2000-luvulla välittäneet tärkeitä myönteisiä viestejä: "'Älä kerro äidille / Queer as folk' toi näkyväksi, että meitä on muitakin ja että me myös kelpaamme näkyville (UH 41)." Tässäkin vastauksessa näkyy silti se, kuinka hankalalta itsensä nimeäminen homoksi voi tuntua heteronormin vahvasti läpitunkemassa yhteiskunnassa. Vastaaja luo suhteisuutta mieluimmin oman yhteisön sisäpuolisiin puhumalla "meistä" sen sijaan, että hän asettuisi avoimesti haastamaan ympäröivää heteronormia nimeämällä itsensä homoksi.

\section{Termien löytäminen: aseksuaalisuus}

Moderni seksuaalisuuskäsitys ohjaa meitä ajattelemaan, että seksuaalinen halu ja siihen liittyvä nautinto on merkittävä osa persoonallisuuttamme ja identiteettiämme (Haataja 2018, 16-17). Tällöin herättää oudoksuntaa, jos joku ilmoittaa seksuaalisen halun puuttumisen olevan hänelle omin tapa määritellä itsensä. Vastaajista kymmenen $(\mathrm{N}=72)$ identifioi kuitenkin itsensä aseksuaaleiksi, joskin he tekivät sen monin eri tavoin ja monista eri syistä (ks. Clarke ym. 2018, 235-236; Taavetti 2015, 29-30, 70-73). Yksi heistä totesi lyhyesti, että "En ole ikinä tullut kovin hyvin toimeen cis-miesten kanssa, en tiedä miksi, en vain pysty rentoutumaan heidän seurassaan eikä meillä ole juteltavaa (UH 7).” Toinen kertoi muistavansa jo alaluokilta sen, kuinka luokkatoverit tivasivat häneltä, kehen luokan pojista hän oli ihastunut:

En muista tarkalleen mitä ajattelin kun minulta kysyttiin kuka meidän luokan pojista oli ihastukseni kohde. Muistan kuitenkin tunteneeni oloni tyhjäksi. [... ] En stressanut asiasta enempää, varsinaiset tunteet tulevat vasta vanhempana, ajattelin. Vähän niinkuin kun alkaa pitämään kahvista. Ironista kyllä en koskaan ruvennut juomaan kahviakaan. (UH 35.)

Näille vastaajille relaationaalinen minäkäsitys ei rakentunut seksuaalisen vuorovaikutuksen kautta. Sen sijaan vastauksista voi lukea sen, kuinka vieraannuttava aseksuaalisuuden kokemus voi olla yhteiskunnassa, jossa heteroromanssiin asettuvan seksuaalisen halun oletus on läpitunkevasti läsnä.

Media ympärilläni kasvatti minut haikalemaan jonkin perään mitä en varsinaisesti edes halua tai tunne. [...] Tiedätkö miltä tuntuu epäillä itseään joka ikinen hetki? Minä tiedän. [... ] Näin käy kun elät maailmassa jossa tunteet, parisuhde, lapset, avioliitto ja seksi luetellaan pääelämäntavoitteiksi ja et itse tunne mitään. (UH 35.) 
Nimen löytäminen omanlaiselle tunne-elämälle ei ollut ollut helppoa aseksuaaleille vastaajille, ja se tapahtuikin useimmiten sattumalta, internetin avulla. Yksi vastaajista törmäsi aseksuaalisuus-termiin ensimmäisen kerran vuonna 2007, luettuaan 15-vuotiaana deviantART-verkkosivuston tekstejä. Hakukoneen avulla hän löysi myös Wikipedia-artikkelin aiheesta yrittäessään ymmärtää omaa "seksiahistustaan" (UH 64). Joskus netistä löytyvät määrittelyt voivat kuitenkin aiheuttaa sen, että tarjollakaan olevaa nimettyä identiteettiä ei tunnisteta omaksi silloin, jos sitä kuvaavat määrittelyt ovat omalle kokemukselle sopimattomia:

Silloin artikkeli ei vielä erotellut seksuaalisen suuntautumisen ja romanttisen suuntautumisen välillä, joten sain käsityksen, että aseksuaalien pitää myös olla aromantikkoja. Ajattelin että ”ai, kai tää seksiahistus tarkottaa vaan sitä, että en oo valmis harrastamaan seksiä”. Tämä lykkäsi identifiointani parilla vuodella. (UH 64.)

Aseksuaaleille suunnatut ryhmät ja chatit ovat laajentaneet kuviteltavissa olevan rajoja ja mahdollistaneet yhteisöllisyyden kokemisen tilanteessa, joka muuten voisi olla hyvin toiseuttava:

Muiden queer-henkilöiden pohdinnat identiteetistä ja seksuaalisuudesta ovat auttaneet minua löytämään itselleni sopivat sanat - todennäköisesti en ilman nettiä edes tietäisi, että aseksuaalisuus on olemassa, koska siitä puhutaan niin tuskallisen vähän julkisessa keskustelussa. (UH 38.)

Vuonna 2016 netistä löytyneet termit mahdollistivat myös tuolloin 18-vuotiaalle asukupuoliselle henkilölle aseksuaaliksi identifioitumisen. Hän kertoo omasta "välähdyksen” hetkestään (Kähkönen 2018, 144) näin:

Kello oli kaksi yöllä ja makasin sängyllä pimeässä huoneessa, kännykkä kädessä. Googlasin puoli tuntia ja näin linkin jossa luki demiseksuaalisuudesta. Olin kuullut siitä joskus, unohtanut. Sen kautta pääsin aseksuaalisuuteen ja pian aromanttisuuteen. Kaikki paino nousi hetkeksi. Ilman internettiä en vieläkään tietäisi kuka olen, hädin tuskin löysin sitä sieltäkään. (UH 35.)

Vastaajien mainitsemat tunteet, kuten ahdistus, tuska ja painon tunne, kertovat siitä jopa kehollisena tuntuvasta ja emotionaalista työstämistä vaativasta ristiriidasta, joka oli syntynyt heidän oman "tyhjän" kokemuksensa ja sen välille, mitä heidän pitäisi ympäristönsä vaatimusten mukaan tuntea (vrt. Craib 1994 ja Roseneil 2006, sit. Lahti 2019, 78). Tämän ristiriidan työstämisessä keskeisenä apuna heille oli ollut se, että he olivat löytäneet uusia termejä oman kokemusmaailmansa nimeämiseen. Termit ja niiden viitoittamat keskustelut välittivät vastaajille ajatuksen siitä, että heille ominainen, seksuaalisesta halusta vapaa tapa asettua suhteeseen muiden ihmisten kanssa oli tunnustettu ja hyväksytty.

Varhaisimmasta kokemuksesta kertovan, vuonna 2007 Wikipedia-artikkeliin turvautuneen vastaajan itseymmärryksen uudelleenrakentumista hidasti merkittävästi se, että hän joutui prosessoimaan lukemansa merkitystä omalle elämälleen monia vuosia yksin. Sen sijaan kymmenen vuotta myöhemmin vertaisryhmissä oli tuotettu runsaasti jaettua ymmärrystä siitä, millaisia erilaisia kokemusmaailmoja aseksuaalisuuteen saattoi liittyä. Joillakin vastaajista saattoi olla jopa lähipiirissä muitakin samoin tuntevia ihmisiä, joiden kanssa he saattoivat pohtia asiaa yhdessä. Näin oli tämän 18-vuotiaan naisen laita, joka kertoi saaneensa runsaasti vertaistukea omille pohdinnoilleen:

Kysyin [ystävältäni, TJ], voinko olla aseksuaali, jos pidän masturboinnista silloin tällöin, jos haluan romanttisen parisuhteen, jos koen seksin ajatuksena hieman ällöttävänä ja kaikkea tähän liittyvää. Hän sanoi, että kyllä, kuulostan aseksuaalilta ja hän linkkasi minulle AVENin nettisivut, jotka kertovat aseksuaalisuudesta ja auttaa siihen liittyen. Koko loppuillan kulutin AVENissa ja Facebookin 
Asexuality-ryhmässä, johon sinä iltana liityin. Kaikki lukemani tarinat sopivat minuun ja kysymyksiini vastattiin positiivisesti. Tajusin olevani aseksuaali. (UH 7.)

Kun tämän vastaajan vuorovaikutukselle altis huokoinen minuus asettui suhteeseen mahdolliseen vertaisryhmään kuuluvien uusien ihmisten ja heidän kertomustensa kanssa, uusi tilanne mahdollisti hänelle uudenlaisen minuuden konstituoitumisen ja kokemuksen henkilökohtaisesta psyykkisestä tilasta (Roseneil \& Ketokivi 2016, 154): "[t] ajusin olevani aseksuaali". Vastauksia lukemalla käy kuitenkin hyvin ilmi se, että aseksuaalisuudeksi nimetty identiteetti saattoi pitää sisällään varsin erilaisia kokemuksia.

Esimerkiksi eräs vastaaja tajusi, että hän ei vielä 17 -vuotiaanakaan ollut kiinnostunut seksistä:

aloin identifioimaan aseksuaalina 17-vuotiaana sen takia, koska en halunnut harrastaa seksiä ja koska en tarkemmin ajateltuani edes tiedä miltä tämä 'seksuaalinen vetovoima' tuntuu (UH 62).

Toisaalta joillekin vastaajille aseksuaaleiksi identifioituminen ei silti sulkenut pois ihastuksia tai seurustelua eri sukupuolia olevien ihmisten kanssa. He saattoivat kutsua itseään bi- tai homoromanttisiksi aseksuaaleiksi, tai aseksuaaleiksi lesboksi (UH 62; UH 7; UH 33; UH 56). Mutta jotkut vastaajista eivät olleet kiinnostuneita solmimaan lainkaan intiimejä suhteita toisiin ihmisiin, vaan kokivat lämpimiä tunteita muista asioista: "Saatan katsella oransseja lehtiä maassa ja vain rakastaa elämää (UH 35)."

Jos yhä edelleen aseksuaalisuudesta puhutaan julkisuudessa harvoin, ei se vuonna 2009 ollut tuttu asia myöskään terveydenhuollon toimijoille. Niinpä tämä vastaaja koki epäasiallista kohtelua kerrottuaan hoitajalleen olevansa aseksuaali. Henkilökunnan asenne vaikeutti hänen sitoutumistaan hoitoihin ja katkaisi sinänsä tarpeellisen hoitosuhteen ennenaikaisesti:
[Hoitaja, TJ] vastasi, että me "työstäisimme sitä". En vieläkään tiedä eikö hän vain ymmärtänyt mitä aseksuaalisuus on vai eikö hän välittänyt. Itse tilanteessa olin niin häkeltynyt, että en osannut reagoida, mutta myöhemmin olin raivoissani. Eheytyshoitoonko minut laitetaan? Hoitaja ei varmasti olisi sanonut samaa heteroille tai edes homoille tai lesboille. Parin tapaamisen jälkeen en mennyt enää sovituille ajoille. (UH 64; vrt. myös UH 29; Taavetti 2015, 124)

Tämä vastaus kertoo siitä, miten tärkeää ihmisille on se, että kaikkia heteroseksuaalista normia nimetysti haastavia henkilöitä kohdellaan yhtälailla kunnioittavasti. Siksi ei tarvitse ihmetellä, miksi toinen vastaaja on niin iloinen siitä, että hän on saanut elää nuoruutensa aikana, jolloin aseksuaalisuus on ollut enemmän esillä ja siitä on ollut saatavilla paremmin tietoa. "Aseksuaalisuuden lisäys joihinkin terveystiedon oppikirjoihin on upeaa (UH 59)." Laajemminkin se, että "oma" termi on olemassa yleisessä käytössä ja tarjolla muiden joukossa rastitettavana ruutuna tai klikattavana valikkona tarjoaa ihmisille kaivatun mahdollisuuden samaistumiseen, mikä kontrastoituu vahvasti paljon tavanomaisempaan väärinolettamiseen ja ohittamiseen (UH 13; UH 29). Samalla termin näkyvyys herättää ihmisissä iloa, usein siksi, että se auttaa normalisoimaan omaa olemassaoloa, sitä samaa, joka usein on pitkään joutunut pysymään nimettömänä ja outona kaapissa (Clarke ym. 2018, 234).

\section{Rinnakkaisten termien käyttäminen: queer, bi- ja panseksuaalisuus}

Vaikka homoseksuaalisuudesta on jo jonkin aikaa puhuttu varsin avoimesti, biseksuaalisuuden osalta tilanne on pitkään ollut toinen. Sen kulttuurinen olemassaolo on edelleen paljon homoseksuaalisuutta vaietumpaa ja leimatumpaa (Kangasvuo 2014; Lahti 2019). Lisäksi sen asema on ambivalentti 
monoseksuaalisiksi asemoituvien hetero- ja homoseksuaalisuuksien välissä. Mutta toisaalta se, että kokemus tulee aina nimetyksi juuri muuttuvassa suhteisuudessa, tekee itsensä nimeämisestä ja varsinkin tämän nimeämisen toistamisesta vaikeaa (ks. Kähkönen 2018, 133). Siksi ihmisten itsestään käyttämät termit eivät välttämättä koskaan muodosta yksiselitteisesti pysyvää jatkumoa esimerkiksi halujen, tekojen ja identiteettien välille (Diamond 2007). Sen sijaan niitä luonnehtii usein tilannesidonnaisuus ja osin jopa satunnaisuus.

Viisi vastaajista määritteli seksuaalisuutensa queeriksi, antaen kuitenkin tälle määrittelylle keskenään hyvin erilaisia sisältöjä. Kolmelle heistä queer ja muunsukupuolisuus tuntuivat liittyvän yhteen (UH 54; UH 68; UH 69). Vaikka trans- ja muunsukupuolisista ihmisistä puhumiselle alkaa jo olla olemassa sanoja, heidän itsensä voi yhä edelleen olla vaikea puhua oman seksuaalisuutensa suuntautumisesta perinteisillä termeillä, jotka olettavat ensisijaisesti kiinnostuksen suuntautumisen asettuvan tavalla tai toisella binäärisukupuoliin (Taavetti 2015, 67). Myös australialaistutkimuksessa on todettu, että erityisesti ne henkilöt, joiden sukupuoli ei asetu binäärisesti, nimesivät seksuaalisen suuntautumisensa mielellään queer-ja panseksuaalisuus-termein (Morandini ym. 2016, 6).

Yksi vastaajista oli nainen, joka oli siirtynyt heterosuhteesta seurustelemaan naisten kanssa, ja oli aluksi nimennyt itsensä lesboksi. Nyt hän kirjoitti, kuinka "[o]len nyt myös 'päivittänyt' käsitystäni itsestäni, lesbo ei ehkä enää kuvaa omaa seksuaalisuuttani yhtä hyvin kuin queer, ja siksi identitifioidun queeriksi (UH 52)”. Toinen heterosuhteista naissuhteeseen siirtynyt nainen nimesi itsensä suoraan queeriksi (UH 5). Ehkä nämä vastaajat kokivat, että queer salli lesboutta paremmin heidän muuttuvan halunsa (myös Sprott \& Hadcock 2018, 223). Suomen lisäksi myös kansainvälisissä tutkimuksissa on todettu, kuinka lesbous on identiteettikategoria, jonka suosio on jo pitkään ollut laskussa erityisesti nuorison parissa (Lehtonen 2014, 53; Herrera 2017, 3, 7; Rosenberg 2006, 9-10). Tämä voi selittyä sillä, että lesbous ymmärretään nykyään tiukkarajaiseksi ja vakaaksi kategoriaksi - ehkä jopa vakaammaksi, kuin mitä monet lesbot sen itse mieltävät.

Toisille queer saattoi alleviivata sellaista poliittista katsantokantaa, joka kritisoi pyrkimystä normaaliuteen (ks. Holma ym. 2018, 60; Taavetti 2015,30 ). Tuolloin kritiikin kohteena saattoi olla esimerkiksi lesbo- ja homoliikkeen tavoittelema yhdenvertainen avioliitto:

En ole ollut koskaan kiinnostunut avioliitosta ja monisuhteisesti elävänä ajatus kahden ihmisen välisestä juridisesti vahvistettavasta liitosta tuntui vain absurdilta ihanteelta. [...] [Kesän 2014 Helsinki Pridella näkynyt, TJ] "Tahdon 2014 vain panna" -iskulause vahvisti käsitystäni siitä, että kutsun itseäni queeriksi nimenomaan siksi, että se kuvastaa myös poliittista minääni. (UH 69.)

Tässä vastauksessa seksuaalisuutta määrittelevä vuorovaikutussuhde omaan lähipiiriin mahdollisti sen, että seksuaalinen identiteetti näyttäytyy myös poliittisena ratkaisuna.

Aiempien luokittelujen suosion hiipuessa määrittelemättömyys kasvattaa suosiotaan (Lehtonen 2014, 53), ja tämänkin keruun vastauksien läpikäynti osoitti sen, että kaikki vastaajat eivät olleet varauksettoman innostuneita oman seksuaalisuutensa määrittelemisestä. Märittelemättömänä pysyttäytyminen voi liittyä esimerkiksi siihen, että vastaaja näkee sukupuolensa ja/tai seksuaalisuutensa olevan liikkeessä, eikä hän siksi halua sitoutua vain yhteen, vakaita rajoja indikoivaan identiteettiperustaiseen kategoriaan. Tämä vastaaja on yksi niistä, joka koki tarjolla olleet binäärikategoriat ahtaiksi:

Ulkopuolisilla ihmisillä on kokemukseni mukaan ollut tarve mää- 
ritellä seksuaalisuuttani. Vaikka olen elänyt pitkissä monogamisissa suhteissa, en ole halunnut määritellä itseäni heteroksi tai lesboksi. Olen aina kokenut olevani jollain tavalla näiden välissä. (UH 18.)

Eräs pelkästään heterosuhteissa ollut nainen, joka kuitenkin koki voivansa kiinnostua romanttisessa ja seksuaalisessa mielessä ihmisistä heidän sukupuolestaan riippumatta, kuvasi itseään näin: "bi-seksuaali/epävarma/en koe tarvetta määrittelyyn" (UH 32). Naissuhteensa virallistanut nainen puolestaan nimesi itsensä panseksuaaliseksi naiseksi, "jos on pakko kategorisoida" (UH34). Itsensä nimeäminen voi tuntua bi- ja panseksuaaleista erityisen hankalalta siksi, että nimeäminen itsessään on liikettä pysäyttävää vallankäyttöä (Butler 1997, 36). Siinä missä kyselyyn vastanneille aseksuaaleille oman paikan vakauttaminen nimeämällä tuntui helpottavalta, bi- ja panseksuaalit tuntuivat puolestaan arvostavan sitä, että heidän avara halunsa sai jatkaa rajoittamatonta liikettään.

Kuitenkin panseksuaalisuus-termin avoimuus tarjosi joillekin vastaajille kaivatun ratkaisun hankalaksi koettuun määrittelyongelmaan, ja auttoi heitä konstituoimaan itsensä aiempaa osuvammin:

Se tunne, kun ymmärsin, että seksuaalinen kiinnostukseni ei rajoitu vain naisiin, vaan henkilöihin sukupuolesta riippumatta. Olen oikeastaan aina tuntenut niin, mutta löysin sille määrittelyn panseksuaalisuus vasta näin 29-vuotiaana tänä vuonna. En tiedä, miksen ollut aiemmin tajunnut tätä asiaa, mutta hyvä näinkin myöhään kuin ei milloinkaan. (UH 34.)

Myös tämä, itsensä aiemmin biseksuaaliksi nimennyt vastaaja, koki panseksuaalisuus-termin löytämisen itselleen myönteiseksi asiaksi:

Olin netin kautta tutustunut moniin lgbtq ihmisiin ja termeihin. Vuotena 2016 olin törmännyt termiin panseksuaali ja ajattelin, että se kuvaa minua hyvin (ja tykkäsin lipun väreistäkin). En ole ikinä ajatellut, että minun seksuaalisuuden esteenä olisi jonkun ihmisen sukupuoli tai sukupuoli ilmaisu ja panseksuaalisuus minulle kuvastaa hyvin sitä mitä tunnen. (UH 65.)

Vastausten perusteella rajanveto bi- ja panseksuaalisuuksien välillä on käytännössä kuitenkin satunnainen ja liukuva (myös Lahti 2018, 22, av. 1).Yksi vastaajista kertoi nimenneensä itsensä biseksuaaliksi lähinnä siksi, ettei hänellä aikoinaan, 25-vuotiaana, ollut vielä ollut käytössään sanaa panseksuaali (UH 1). Siinä missä toinen vastaaja nimesi identiteettinsä biseksuaalista panseksuaaliksi 29-vuotiaana opittuaan uuden, häntä aiempaa osuvammin kuvaavan termin (UH 19), kolmas keruuhetkellä 21-vuotias vastaaja ei tuntenut siihen erityistä tarvetta:

Näin vuosien jälkeen olen pohtinut, että yhtälailla voisin varmastikin identifioitua panseksuaaliksi, sillä sukupuolella ei ole minulle väliä. En kuitenkaan jaksaisi jälleen tulla kaapista ja identifioitua uuteen identiteettiin. Biseksuaalisuus tuntuu tällä hetkellä hyvältä ja minulle sopivalta. (UH 2.)

Voisi myös ajatella, että henkilön bi- tai panseksuaalinen itsemäärittely helpottaisi hänen suhtautumistaan sukupuolen moninaisuuteen ja siirtymiin, niin omiin kuin muidenkin. Näin vaikuttaa olevan myös aineistossa. Nainen, joka rakastui ensimmäistä kertaa 14-15-vuotiaana sukupuolettomaan henkilöön, on sen jälkeen mieltänyt itsensä panseksuaaliksi (UH 17), kun taas biseksuaaliksi identifioituva cisnainen kertoi muistelussaan suhteestaan transnaiseen (UH 44). Useat transmiehet ja transmaskuliiniset muunsukupuoliset nimesivät bi- tai panseksuaalisuuden omimmaksi seksuaaliseksi identiteetikseen (UH 9; UH 16; UH 61; UH 65; UH 66). Tämä voi johtua myös siitä, että joillakin henkilöillä transitioprosessi saattaa laittaa liikkeeseen myös seksuaalisen suuntautumisen, kun taas hetero- ja homoseksuaalisuuden kaltaiset termit tuntuvat olettavan vakaita identiteettejä (Rosenberg 2017, 5). Tällöin queer voi tuntua parhaalta ter- 
miltä, sillä se tarjoaa tilaa myös niiden ihmisten seksuaalisuudelle, joiden sukupuoli on liikkeessä (Holma ym. 2018, 60; Morandini ym. 2016, 1,9).

Samaan tapaan ne vastaajat, joille BDSM-seksikäytännöt olivat keskeisen tärkeitä heidän seksuaaliselle identiteetilleen, nimesivät itsensä tavallisimmin bi- tai panseksuaaleiksi (UH 37; UH 17; UH 44). Ehkä näille naisille kinky seksuaalisuus avasi mahdollisuuksia sukupuolierottelusta riippumattoman seksuaalisen mielihyvän tutkimiseen ja päinvastoin (Sprott \& Hadcock 2018, 225).

Jotkut vastaajat taas väistivät kategorisesti sellaista nimeämistä, joka edellyttäisi sukupuolen olemassaoloa. He saattoivat kuvata seksuaalisen kiinnostuksensa suuntautuvan esimerkiksi "konsensuaalisuuteen kykeneviin aikuisiin ihmisiin" (UH 16). Tällainen määritelmä laajentaa ja haastaa edelleen sukupuoliin sitoutunutta ajattelua seksuaalisesta identiteetistä, orientaatiosta ja käyttäytymisestä ottaessaan mukaan ja eksplikoidessaan iän ja suostumuksen halulle merkityksellisinä kategorioina.

Kaikki nämä vastaajat pyrkivät tekemään omaa seksuaalista kokemusmaailmaansa ymmärrettäväksi muille itsensä nimeämisen kautta. Osoittautui kuitenkin, että tämä ei ole helppoa, saati yksiselitteistä, sillä käytetyt termit ja niiden merkityssisällöt saattoivat olla hyvinkin muuttuvia ja vaihtuvia riippuen niistä vastavuoroisista suhteista, joissa vastaajat nimesivät ja (uudelleen)konstituoivat itseään. Itsensä nimeäminen on aina investointi termin tarjoamaan merkitysmaailmaan, joka kuitenkin saattaa ajan myötä osoittautua puutteelliseksi tai sopimattomaksi. Parhaimmillaan termit tarjoavat silti edes väliaikaisen keinon kuvata muillekin käyttäjänsä kokemuksellista tuntoa.

\section{Termien tietoinen luominen: esimerkkinä muunsukupuolisuus}

Joillekin vielä ilmaisuaan hakeville tuntemuksille ja kokemuksille saattaa olla aluksi vaikea löytää sanallista muotoa. Muistitietokyselyn vastauksista välittyy hyvin se, että tällaisia kysymyksiä vilkkaimmin pohdiskelevat nettikeskustelut löytyvät usein englanninkielisiltä verkkosivustoilta. Niillä suomenkielinen liikkuja joutuu kuitenkin hahmottamaan omaa identiteettiään vieraalla kielellä, eikä kaikille siellä tarjolla oleville termeille löydy helposti äidinkielistä vastinetta. Tällöin englanninkielisiä termejä, kuten vaikkapa transgender, demigender, genderfluid, genderqueer tai gender nonconforming yritetään kotouttaa vaihtelevalla menestyksellä sellaisenaan suomen kieleen (Aarnipuu 2008, 78-80; Järviö 2018, 38-39), mikä sekin voi tuottaa omanlaista vierautta omaan kokemukseen. Joillekin termeille pyritään luomaan sukupuolisopeutumattomuuden kaltaisia käännöksiä (Rossi 2017, 6), mutta aineistossa esiintyi myös kotimainen uudissana muunsukupuolisuus.

Vastaajista 11 luonnehti sukupuoltaan sanalla muu tai muunsukupuolinen. Vaikka kokemus sukupuolisesta toiseudesta saattoi olla hyvinkin varhainen palautuen esimerkiksi sellaiseen hetkeen, jolloin keski-ikäinen kirjoittaja kertoo tajunneensa viisivuotiaana pettymyksekseen, ettei hän koskaan voisi olla poika (UH 55), ilmiötä kuvaava suomenkielinen termi muunsukupuolisuus on paljon myöhempää perua. Aktivistien kielenkäytöstä se on vakiintunut tieteellisiin teksteihin vasta vuosien 2013-2016 välisenä aikana (Järviö 2018,38). Muunsukupuolisuuden ensiesiintyminen yhteisöllisissä keskusteluissa on keruuseen tulleiden vastausten mukaan ollut WTFTM-keskustelupalstalla syksyllä 2008 (UH 54). WTFTM.org oli perustettu turvalliseksi tilaksi "kaikille syntymässä naiseksi määritetyille, jotka kokivat sukupuoliristiriitaa, riippumatta siitä olivatko he transmiehiä tai jotain muuta (UH 68)”. 
Tämä muistitietokyselyyn vastannut henkilö muistaa muunsukupuolisuus-termin ensiesiintymisen keskustelufoorumilla erityisen hyvin. Hän kirjoittaa, kuinka hän 20-vuotiaana tunsi tarvitsevansa uutta termistöä:

Niihin aikoihin yleisin sana kuvaamaan ei-binääriyttä oli Suomessa "transgender", jota kohtaan olin aina potenut närkästystä, koska se sekoittui englannin kielessä käytettävään identtiseen termiin vaikkei tarkoittanut samaa. Eikä se ollut suomea. [...]. ”Transgender" myös kuulosti transsukupuolisuuden kevytversiolta, jossa merkityksessä sanaa usein käytettiinkin. Koin olevani transsukupuolinen yhtä lailla kuin miehiksi ja naisiksi identifioituvat, joten halusin sanan, joka ei ota kantaa trans-statukseeni vaan sukupuoli-identiteettiini.

Käytössä olivat myös ”androgyyni” ja "sukupuolineutraali" tai "neutri", mutta ne eivät kuvastaneet minun omaa sukupuoltani. Jos ei ollut sukupuoleltaan sekä-että, kuten androgyyni, eikä neutraali tai sukupuoleton, olemassaolevat sanat eivät riittäneet. Halusin jotain epämääräisempää, jonka alle mahtuisi vaikkei osaisi tarkalleen määritellä mistä osasista oma sukupuoli koostuu, ja mikä ei ottaisi kantaa mieheyteen tai naiseuteen muuten kuin asettumalla niiden ulkopuolelle.

Halusin omaan äidinkieleeni sanan, jonka merkityksen jopa asioihin perehtymätön ymmärtäisi heti. Halusin sanan, jota ei tarvitsisi selittää cissukupuolisille - olin kyllästynyt selittelemään, vakuuttelemaan ja korjaamaan väärinkäsityksiä.

"Muunsukupuolinen" tuntui sanana itsestäänselvältä. Sitä ei voi olla ymmärtämättä, vaikka haluaisi. (UH 54).

Hänen kirjoitettuaan uuden termin keskusteluryhmään ensi kertaa vuonna 2008, se levisi sieltä ensin vertaisryhmiin ja sitten niiden ulkopuolelle myös asiateksteihin ja yleiseen kielenkäyttöön. Niistä yhä uudet ihmiset löysivät termin tunnistettuaan, kuinka he sen avulla kykenivät entistä paremmin kuvaamaan itseään ja omaa sukupuolikokemustaan.

Sana jäi kuitenkin kytemään mieleeni ja vähitellen aloin kuvaamaan itseäni tällä sanalla, joka tuntui omalta ja jonka avulla tuntui aiempaa helpommalta kommunikoida myös cissukupuolisille omasta sukupuolesta (UH 66).

Yhä nuoremmat ihmiset löysivät muunsukupuolisuus-termin ansiosta tavan kuvata omaa olemisen tapaansa, kuten esimerkiksi ne kaksi vastaajaa, jotka jo 13-vuotiaana löysivät muunsukupuolisuuden itsemäärittelykseen, yksi heti vuonna 2008 (UH 33) ja toinen vuonna 2013 (UH 60). Mutta helposti avautuva termi puhutteli yhtä hyvin myös vanhempia vastaajia. Yksi kirjoittajista oli jo 45-vuotias, kun hän päätyi vuonna 2012 määrittelemään itsensä muunsukupuoliseksi (UH 6). Toinen kirjoittaja alkoi pohtia sukupuoltaan 41-vuotiaana tajuttuaan, että ei lainkaan identifioidu naiseuteen, toisin kuin esimerkiksi hänen naisystävänsä. Kaksi vuotta myöhemmin vastatessaan kyselyyn hän ajatteli olevansa muunsukupuolinen: "Kaiken kaikkiaan tämä on ollut hieno, mutta myös hämmentävä oivallus. En tiedä, olisinko ymmärtänyt itseäni ennen paremmin, jos minulla olisi ollut enemmän tietoa ja sanoja asioille." (UH 22.)

Erityisesti monet transmaskuliiniset henkilöt, jotka eivät ole pitäneet sukupuolenkorjausprosessiin lähtemistä ajankohtaisena tai tarpeellisena itselleen, ovat löytäneet muunsukupuolisuudesta sopivan itsemäärittelyn (UH 16; UH 55; UH 66). Joku taas käyttää muunsukupuolisuutta synonyymisenä käännöksenä gender queer ja gender fluid -termeille (UH 69). Muunsukupuolisuus on yksinkertaistanut myös intersukupuolisten ihmisten itsemäärittelyä (UH 16), sillä se ei pakota heitä valitsemaan jompaakumpaa kahdesta sukupuolesta.

Monille oman sukupuoli-identiteetin prosessointi on tapahtunut vain 
omassa päässä ja yksin. Jotkut vastaajista ovat kuitenkin kyenneet peilaamaan omaa muunsukupuolisuuttaaan mahdollisen verkkoyhteisön ohessa alakulttuuripiireissä kasvokkain kohtaamiinsa ihmisiin. Yksi heistä kirjoittaa kokemuksestaan näin:

[Keikoilla, TJ] kohtasin ensimmäisen kerran prosessin läpikäyneitä muunsukupuolisia. Se oli niin kiehtovaa, että aloin käydä [keikoilla, TJ] lähes pakkomielteisesti vain kohdatakseni näitä ihmisiä uudestaan [...]. Kun katsoin heitä, minusta tuntui, että olin viimein kohdannut omiani. (UH 49)

Samoin esimerkiksi Peijakas!-klubi-illat Helsingissä ovat nostaneet jo kymmenen vuoden ajan esiin naisia ja muunsukupuolisia dj:tä ja muusikoita, ja tehneet näin turvallista tilaa sukupuolen ja seksuaalisuuden moninaisuudelle (UH 20). Toisille oma alakulttuurinen yhteisö on löytynyt kuin vahingossa erilaisten kulttuurituotteiden fanituksen myötä (UH 61; UH 66). Esimerkiksi joihinkin japanilaisiin musiikkityyleihin ja niiden fanikulttuureihin liittyvät keskeisesti sukupuolineutraalius, androgyynisyys ja binäärin ulkopuoliset identiteetit, joiden vastaajat kokivat tukevan myös heidän omaa itseilmaisuaan (UH 66). Erilaisten populaarikulttuuristen ilmiöiden ympärille muodostuvat fanikulttuurit ovatkin monille sukupuoltaan pohtiville tärkeitä vertaisyhteisöjä (Jenzen 2017, 1635).

Vaikka muunsukupuolisuus on iskevänä suomenkielisenä sanana lyönyt itsensä hyvin läpi myös julkisessa keskustelussa, sitä kohtaan on esitetty myös kritiikkiä. Esimerkiksi Näkymätön sukupuoli -teoksessa haastateltu henkilö kutsuu itseään muunsukupuolisen sijaan mieluimmin queeriksi, koska siinä ei ole hänen toiseuttavaksi tulkitsemaansa muu-etuliitettä (Holma ym. 2018, 98). Jotkut ihmiset eivät samaistu sukupuolikokemukseen lainkaan, ja heille osuvimmalta itsemäärittelyltä tuntuu sukupuolettomuus (mt., 57, 107, 109) tai asukupuolisuus (UH 35).
Myös muistitietokyselyn vastaaja tunnistaa kritiikin ja hyväksyy sen tarpeellisuuden:

Pointit ovat olleet hyviä; "muu" sanana on toiseuttava ja epämääräinen. Termi ei myöskään sisällä sukupuolettomia henkilöitä, minkä takia onkin hyvä että monissa paikoissa luetellaan erikseen "miehet, naiset, muunsukupuoliset ja sukupuolettomat". (UH 54.)

Tämä muunsukupuolinen-termiin kohdistettu kritiikki tekee myös näkyväksi sitä, kuinka termit, toimivatkaan, eivät ole kaiken kattavia tai ikuisia. Kun termit otetaan käyttöön, ne myös muuttavat keskusteluavaruuksia ja tekevät samalla tilaa yhä uusille nimeämisen tavoille. Jotkut termit jäävät kiistojen kohteeksi, toiset taipuvat niitä kohtaan esitettyihin muutosvaatimuksiin tai hiipuvat käytöstä tarpeettomina.

Muunsukupuolisuus-termin kohdalla toistuu jälleen se havainto, kuinka itseä osuvasti kuvaavan termin löytäminen on lisännyt vastaajien itseymmärrystä ja tarjonnut mahdollisuuksia yhteisöjen löytämiseen. Samalla se on mahdollistanut oman tilanteen kommunikoimisen muille entistä paremmin.

\section{Muotoaan hakeva termistö: suhdemuotojen kuvaaminen}

Muistitietovastauksissa näkyy jossain määrin myös parisuhteisuuden nimeämiseen liittyvää keskustelua. Suuri joukko, yhteensä 13 vastaajaa, nosti yhdenvertaisen avioliittolain hyväksymisen yhdeksi tärkeimmäksi unohtumattomaksi hetkekseen. Heille joko jo toteutunut tai potentiaalinen avioliitto häineen, sormuksineen ja mahdollisuuksineen kutsua omaa puolisoa legitiimisti vaimoksi olivat tärkeitä askeleita nimenomaan yhdenvertaisuuden näkökulmasta. 
Olin tähän saakka hieman nolostellut sitä, että seurustelen naisen kanssa. Koin, etten ole yhtä oikea aikuinen kuin esimerkiksi serkkuni. Koen niin edelleen, mutta avioliittolaki on auttanut paljon karistamaan tätä outouden tunnetta. (UH 19.)

Avioliiton myötä parisuhdetta kuvaavilla termeillä ei enää tehdä eroa hetero- ja homoseksuaalisten suhteiden välillä, toisin kuin vielä silloin, kun avioliiton rinnalla puhuttiin myös rekisteröidyistä parisuhteista. Tämä muutos on ollut osalle vastaajista tärkeä askel paitsi normalisoitumisen, myös itsehyväksynnän suuntaan (ks. Taavetti 2015, 144-147). Heille suhdetta kuvaavan termin muutos muutti myös heidän kokemustaan ja konstituoi heitä ja heidän toimijuuttaan uudella tavalla.

Mutta heidän rinnallaan keruussa näkyi myös pieni joukko niitä, joille parisuhdenormatiivinen ja yksiavioiseksi ajateltu seurustelu tai avioliitto ei ollut se tapa, jolla he halusivat järjestää intiimisuhteensa. Sen sijaan he olivat löytäneet yhteiseen sopimukseen perustuvasta monisuhteisuudesta itselleen sopivan tavan järjestää elämänsä joko osana avioliittoaan tai muuta avointa suhdeverkkoa (UH 17; UH 21; UH 69). Sekä Näkymätön sukupuoli -teoksessa että aiemmassa suomalaisessa tutkimuskirjallisuudessa nousee monisuhteisuus esiin polyamorian muodossa (Holma ym. 2018, 85, 132, 155; Taavetti 2015, 30,32, 66). Se, että Suomessakin julkiseen keskusteluun nousee tapoja väljentää anarkistisesti rajaa ystävyyden ja rakkauden välillä, tai ylläpitää suostumukseen perustuvia rinnakkaisia suhteita useampien kumppanien kanssa vahvistaa osaltaan aiempaa havaintoa siitä, että ihmissuhteiden solmiminen on nousemassa (irto)seksiä tärkeämmäksi tavaksi järjestää monimuotoista seksuaalielämää (Clarke ym. 2018, 232). Relaationaalinen ajattelumalli ilmenee myös uudenlaisena kiinnostuksena suhdekäytäntöihin. Siinä missä aiemmin oli tärkeää todistaa oma seksuaalinen suuntautuminen seksuaalisilla teoilla, huomio kiinnittyy nyt seksuaalisista teoista eri muotoisten suhteiden luomiseen ja ylläpitämiseen, joihin saattaa liittyä tai olla liittymättä seksuaalista kanssakäymistä.
On myös kiinnostavaa nähdä, käykö niin, että jatkossa tällekin kentälle syntyy lisää nimettyjä vaihtoehtoja, samaan tapaan kuin sukupuolen ja seksuaalisuuden termeille on jo käynyt. Esimerkiksi vuodesta 2017 alkaen näkyy enenevästi merkkejä siitä, että julkisessa keskustelussa pariskuntien rinnalle on alettu nostaa moniskuntia (esim. Parisuhdekeskus Kataja). Jos näin käy, laajeneva termistö avaa osaltaan uusia mahdollisuuksia parisuhdenormatiivisuuden haastamiseen ja suhdemuotojen toisin toistamiseen.

Olemassa olevan käsitteistön riittämättömyys koski aineistossa yllättäen myös kyseenalaistamattomana itsestäänselvyytenä kohdeltua heteroseksuaalisuutta. Jos oletetusti heteroseksuaalisten ihmisten ei ole koskaan tarvinnut miettiä omaa identiteettiään, se merkitsee myös sitä, että heidän heteroseksuaalisuutensa voi jäädä hauraaksi ja hahmottomaksi (Taavetti 2015 , 143). Silloin kun naisvastaajat ovat rakentaneet omaa suhteisuuttaan miesehtoisen heteronormin rajoissa, siitä puuttuu kyseenalaistuksen tuoma omakohtainen pohdinta. Tällä tavoin hauraaksi jäänyt itseymmärrys puolestaan altistaa erityisesti naiset ulkopuoliselle painostukselle niin sukupuolen ilmaisun kuin seksuaalisuutensa toteuttamisen tapojenkin suhteen. Yksi vastaajista kuvaili havahtumistaan omaan pakkoheteroseksuaaliseen tilanteeseensa, kun hän 11 vuoden seurustelun jälkeen joutui yllättäen arvioimaan elämäänsä uudelleen:

[...] järki yritti pakottaa mua takaisin siihen heteroseksuaaliseen suhteeseen, jossa olin elänyt teinistä saakka, osittain pakotetusti. Pakottamisella tarkoitan sitä, että olin huonon itsetunnon takia aina ajatellut, etten voi saada mitään parempaa suhdetta elämässäni, en ole minkään arvoinen ja täytyisi elää ikuisessa kiitollisuuden velassa ex-miehelle siitä, että se edes jaksoi katsella mua. (UH 52.)

Tässä vastaaja nimesi heteroparisuhteessa elämisen aiheuttaneen hänelle itsetunnon murenemista, emotionaalista riippuvuutta miespuolisesta kumppanistaan ja kaikinpuolista vaihtoehdottomuutta. Vastaavien ko- 
kemusten kuvaukset muussa aineistossa herättävät ajatuksen siitä, että myös heterosuhteen tuottamille ongelmille saatettaisiin tarvita enemmän kriittistä termistöä kuin mitä siihen on tällä hetkellä tarjolla.

\section{Tunnistettavat ja tunnustavat termit luovat suhteisuutta}

Sanan löytäminen omalle identiteetilleni on ollut hyvin tärkeä tapahtuma elämässäni, joka on vaikuttanut siihen, miten uskallan ottaa tilaa maailmassa ja millaisen itseilmaisun näen mahdollisena (UH 66).

Tässä artikkelissa olen analysoinut niitä moninaisia tapoja, joilla henkilökohtainen kokemus sukupuolesta ja seksuaalisuudesta on kerrottu Unohtumattomat hetket -keruuvastauksissa vuonna 2018. Aineiston analyysi osoitti, että useimmat vastaajat kaipasivat sukupuolen ja halun kokemuksilleen osuvia termejä. Minuutta määrittelevät termit auttoivat heitä (uudelleen) konstituoimaan subjektiuttaan samalla kun nimetty identiteetti tuotti heille käsityksen omasta toimijuudestaan. Identiteettikokemusta nimeävät termit ovat vuorovaikutteisia: niitä luodaan ja käytetään suhteessa itseen, mutta ennen kaikkea termit tarjoavat muille mahdollisuuden tunnistaa käyttäjänsä tavalla, jonka ihmiset itse kokevat omakseen. Ajassa liikkuvia termejä käytetään sekä yhteenkuuluvuuden luomiseen että erojen tekemiseen.

Jäsentelin aineistosta kerättyjä termejä ja niihin liittyvää kokemuskerrontaa erilaisten nimeämiseen liittyvien mahdollisuuksien kautta. Tosin usein kyse oli myös mahdottomuudesta; kävi ilmi, että monien vastaajien oli vaikea nimetä itseään vallitsevilla normatiivisilla identiteettikäsitteillä. Pyrkimykset asettua cis- ja heteronormatiivisen odotusten mukaisesti nimettyihin identiteettipositioihin aiheuttivat vastaajille ristiriitaisia tunteita, mikä tuotti vierautta ja raskautta oman itsensä kokemiseen. Osuvien termien puuttuminen teki heille mahdottomaksi niin oman kokemuksensa tunnistamisen kuin luonteviin suhteisiin asettumisen muiden ihmisten kanssa.

Toisaalta vastaajat kuvasivat myös niitä tilanteita, joissa nimeämisen ympärille rakentuvat vertaiskohtaamiset mahdollistivat heille uudenlaisen identiteetin omaksumisen. Osuvan termistön löytäminen joskus pitkänkin etsiskelyn jälkeen tarjosi vastaajille huojentavan kokemuksen siitä, että he olivat vihdoin tunnistaneet oman itsensä. Sopivan termin löytäminen auttoi vastaajia käsittelemään omia kokemuksiaan ja liittämään ne osaksi laajempaa yhteisöllistä kontekstia esimerkiksi aseksuaaleina. Näissä kokemuksissa painottuivat suhteisuuden ne puolet, joissa myönteisellä tavalla korostuivat liittyminen ja joukkoon kuuluminen.

Oleellista on huomata, että samatkaan termit eivät koskaan kuvaa kaikille käyttäjilleen samoja merkityssisältöjä, ja toisaalta samat merkityssisällöt voivat saada kuvaajikseen erilaisia termejä. Tämä korostui vastauksissa erityisesti queer-, bi- ja panseksuaalisuustermien ambivalentissa käytössä. Niissä näkyy myös suhteisuuden luomisen sopimuksenvaraisuus: käytettyjen sanojen valintaa ohjaa usein ennen kaikkea sujuvan vuorovaikutuksen ylläpitäminen, jolloin käyttöön otetaan mieluusti sana, joka on "helppo": se tarjoaa riittävästi yhteistä kosketuspintaa niin, että kommunikaatiota on mahdollista jatkaa (Herrera 2017, 7, 9, 11). Näiden termien käyttöä kuvaavissa vastauksissa näkyi myös se, miten suhteisuutta määritellään myös erottautumisen kautta - kun minuutta konstituoivaa suhdetta luodaan johonkin, se edellyttää myös erottautumista jostain muusta ja näiden ei-toivottujen seikkojen ulossulkemista identifioitumisen piiristä.

Osasta vastauksista kävi myös ilmi, että kun vuorovaikutuksen keskiössä on sellaisten kokemusten jakaminen ja nimeäminen, joita ei voi kuvata jo olemassa olevilla termeillä, se tuottaa uusia termejä ja luo samalla uusia olemisen tapoja. Suomenkielessä muunsukupuolisuus on tästä yksi hyvä 
esimerkki. Kriittistä itserefleksiivisyyttä ja erottautumista omanlaisekseen tarkastelin lisäksi suhdemuotojen uudelleennimeämisen valossa. Erityisesti keskusteluun arvaamatta ilmestyvien uusien termien ymmärrettävyys ja siten kyky konstituoida toimintakykyisiä subjekteja on kuitenkin kiistanalainen. Niiden toimivuus on ratkaisevasti kiinni termin kulloisestakin sosiaalisesta kontekstista, sen tarjoamista diskursiivisista tulkintakehyksistä ja mahdollistamasta suhteisuudesta.

Sukupuolen ja seksuaalisuuden nimeämistä koskeva tietovalta on tähän asti ollut pääsääntöisesti lääkäreillä ja viranomaisilla. Aineistossa kerrotaan myös niistä ongelmista, joita muun muassa asiointilanteissa syntyy silloin, kun osapuolilla ei ole käytössään yhteisesti jaettuja termejä ja ymmärrystä sukupuolen ja seksuaalisuuden moninaisuudesta. Yhteisen termistön puuttuminen voi näkyä esimerkiksi ongelmallisena outoutena ja kohtaamattomuutena (Taavetti 2015, 124-125). Kun ihmiset eivät pysty nimeämään omaa olemistaan yksiselitteisesti tai ymmärrettävästi yhdellä sanalla, heille voi helposti tulla tunne siitä, että he joutuvat tällöin avautumaan muille joko liikaakin omista asioistaan tai vaihtoehtoisesti jäämään ulkopuolisiksi ja vieraiksi.

Tällaisille kohtaamattomuuden kokemuksille vastakkaiseksi asettuu - nykyisin usein verkossa muodostuvissa - vertaisryhmissä tapahtuva tiedontuotanto, jossa termien merkityksistä neuvotellaan yhdessä ja niiden sisällöistä luodaan yhteisymmärrystä. Kun sukupuolen ja seksuaalisuuden moninaisuutta koskeva tietovalta otetaan tällä tavoin lääkäreiltä ja muilta viranomaisilta omiin käsiin, se merkitsee asiantuntijatiedon roolin radikaalia kyseenalaistumista (Haataja 2019, 55). Vaikka normatiivisten asiantuntijakäsitysten haastaminen on ilman muuta tarpeellista, ongelmallisena voidaan pitää sitäkin, jos vertaisryhmät nyt vuorostaan määrittelevät nimetyille identiteettikokemuksille ahtaan, velvoittavan ja muuttumattoman totuusarvon ja olemisen tavan.
Suhteisuuden kautta tarkasteltu muistitietoaineistoaineisto osoittaa omalta osaltaan, että ajatus ulkopuolelta annetusta tai edes itselle selvästä ja lähtökohtaisesti tiedettävissä olevasta vakaista sisäisistä identiteeteistä ei ole toimiva tapa lähestyä sukupuolen ja seksuaalisuuden kokemusta. Hedelmällisempää on käsitteellistää identiteetti minuutta merkittävästi määritteleväksi nimetyksi kokemukseksi. Tämän käsitteellistyksen kautta voimme lähestyä sekä sitä, miten erilaisissa suhteissa syntyvät kokemukset tarjoavat meille yhä uusia identifioitumisen paikkoja, että sitä, kuinka (pois)paikantumista tarjoavat identiteettitermit avaavat meille uudenlaisia kokemusmaailmoja. Tällainen näkökulma auttaa ymmärtämään paremmin sitä, kuinka identiteetit eivät koskaan vain "ole" "omia", vaan rakenteet ja kulttuuriset merkitykset osallistuvat niitä määrittelevien kokemusten tuottamiseen.

Suhteisuuden näkökulmasta on myös selvää, kuinka ristiveto edes hetkellistä pysyvyyttä tarjoavien identiteettitermien ja vuorovaikutuksessa jatkuvasti muuttuvien kokemusten välillä on väistämätön. Tämä ristiriita puolestaan ruokkii seksuaalisuuden ja sukupuolen liikkuvuuden ja moninaisuuden herkeämätöntä itsereflektointia, mikä sekin näkyy osassa aineistoa. Marika Haataja kuvaa heteroseksuaalista nautintoa käsittelevässä tutkimuksessaan jatkuvaan oman kokemuksen reflektointiin perustuvaa omaksi itseksi tulemisen prosessia paitsi mahdollisuudeksi, myös velvollisuudeksi (Haataja 2019, 61). Taksonominen tapa nimetä omia kokemuksiaan ja tunteitaan sukupuolen ja seksuaalisuuden saralla yhä tarkemmin voidaan nähdä osana tätä samaa velvoitetta: jokaisen on valittava oma yksilöllisyytensä yhä uudelleen ja kannettava myös vastuu valinnoistaan.

On ilmeistä, että käynnissä olevan muutoksen ymmärtäminen ja seuraaminen edellyttävät esimerkiksi tutkimukselta sitä, että sukupuolta ja seksuaalisuutta koskevien kaksijakoisten termien rinnalle tuodaan avarampia käsitteellistämisen tapoja, jotka mahdollistavat sen, että "binäärin 
ulkopuoliset identiteetit [hyväksytään, TJ] silmää räpäyttämättä (UH 66)”. Osuvien ja moninaisten termien viljeleminen niin tutkimuksissa kuin eri medioissakin voisi parhaimmillaan johtaa siihen, että yhä useampien ihmisten arki olisi yhtä vaivatonta kuin Pride-kulkueeseen osallistuminen:

Oli ihanaa tulla nähdyksi, tulla tunnetuksi sellaisena kuin olen. Että omaa queeriyttään ei tarvinnut sanallisesti ilmaista, koska se oli jo lähes oletuksena. (UH 38.)

\section{Arkistoaineisto}

UH - Unohtumattomat hetket -muistitietokeruu. Työväen muistitietotoimikunta, Työväen Arkisto.

\section{Verkkoaineistot}

Parisuhdekeskus Kataja URL: https://parisuhdekeskus.fi/blog/avainsana/ moniskunnat/ (luettu 15.3.2019)

Väisänen, Mikko 2014. Nimeämisen sateenkaareva ihanuus. Julkaistu alun perin Kielikuvia-lehdessä 2/2013. Seta. https://seta.fi/2014/02/11/nimeamisensateenkaareva-ihanuus/ (luettu 21.10.2019)

\section{Kirjallisuus}

Aarnipuu, Tiia. 2008. Trans - sukupuolen muunnelmia. Helsinki: Like.

Butler, Judith. 1997. Excitable speech: a politics of the performative. London: Routledge.

Butler, Judith. 2006 [1990]. Hankala sukupuoli. Suomentaneet Tuija Pulkkinen ja Leena-Maija Rossi. Helsinki: Gaudeamus.
Cavalcante, Andrea. 2018. "Tumbling into Queer Utopias and Vortexes: Experiences of LGBTQ Social Media Users on Tumblr". Journal of Homosexuality, online first, DOI: 10.1080/00918369.2018.1511131

Clarke, Kyra, Rob Cover ja Peter Aggleton. 2018. "Sex and ambivalence: LGBTQ youth negotiating sexual feelings, desires and attractions". Journal of LGBT Youth, 15:3, 227-242, DOI: 10.1080/19361653.2018.1469449

Craib, I. 1994. The Importance of Disappointment. London: Routledge.

Diamond, Lisa M. 2008. Sexual fluidity: Understanding women's love and desire. Cambridge: Harvard University Press.

Doan, Laura. 2013. Disturbing Practices History, Sexuality and Women's Experience of Modern War. Chicago: University of Chicago Press.

Ekrem, Carola. 2016. "Att berätta eller rapportera sitt liv". Teoksessa Kirjoittamalla kerrotut. Kansatieteelliset kyselyt tiedon lähteinä, toimittaneet Pirjo Korkiakangas, Pia Olsson, Helena Ruotsala ja Anna-Maria Åström. Helsinki: Ethnos, 80-102.

Haataja, Marika. 2018. "Tavoittelemisen arvoinen nautinto suomalaisissa seksuaaliopaskirjoissa". Kulttuurintutkimus 35:1-2, 15-25.

Haataja, Marika. 2019. Ohjattuja seksuaalisia nautintoja. Tampereen yliopiston väitöskirjat 124. Tampere: Tampereen yliopisto.

Hammack, Phillip L., David M. Frost ja Sam D. Hughes. 2018. "Queer Intimacies: A New Paradigm for the Study of Relationship Diversity". The Journal of Sex Research, online first. DOI: 10.1080/00224499.2018.1531281

Herrera, Andrea P. 2017. "Theorizing the lesbian hashtag: Identity, community, and the technological imperative to name the sexual self". Journal of Lesbian Studies, online firstXX, DOI: 10.1080/10894160.2018.1384263

Holma, Jenni, Veera Järvenpää ja Kaisu Tervonen (toim.). 2018. Näkymätön sukupuoli. Ei-binäärisiä ihmisiä. Helsinki: Into/Voima.

Jenzen, Olu. 2017. "Trans youth and social media: moving between counterpublics and the wider web". Gender, Place \& Culture, 24:11, 1626-1641, DOI: 10.1080/0966369X.2017.1396204

Jones, Nicole K. ja Melanie E. Brewster. 2017. "From awareness to action: Examining predictors of lesbian, gay, bisexual, and transgender (LGBT) Activism for heterosexual people". American Journal of Orthopsychiatry, $87: 6,680-689$.

Juvonen, Tuula ja Marjo Kolehmainen (toim.). 2018. Affective Inequalities in Intimate Relationships. London: Routledge. 
Juvonen, Tuula. 2002. "Niin makaa kuin petaa. Lomaketutkimuksen ongelmat ja homoseksuaalisuus suomalaisissa seksitutkimuksissa". Sosiologia 39:4, 309-321.

Juvonen, Tuula. 2014. "Tutkimusaineistojen arkistoinnista ja bittiavaruuksista". SQS - Journal of Queer Studies in Finland 8:1-2, 58-64.

Juvonen, Tuula. 2015. Kaapista kaapin päälle. Homoseksuaaliset ihmiset ja heidän oikeutensa edustuksellisessa politiikassa. Tampere: Vastapaino.

Järvinen-Tassopoulos, Johanna. 2011. "Pelaavien naisten nettikeskustelujen käytön ja analyysin eettiset haasteet”. Teoksessa Tekstien rajoilla. Monitieteisiä näkökulmia kirjoitettuihin aineistoihin, toimittaneet Sami Lakomäki, Pauliina Latvala ja Kirsi Laurén. Helsinki: Suomalaisen Kirjallisuuden Seura, 202-229.

Järviö, Nina. 2018. Polkuja suomalaiseen tasa-arvoon? Kansalaistoiminta, Tahdon2013-kampanja ja translaki. Helsinki: Helsingin yliopisto.

Kangasvuo, Jenny. 2014. Suomalainen biseksuaalisuus. Käsitteen ja kokemuksen kulttuuriset ehdot. Acta Universitatis Ouluensis B Humaniora 121. Oulu: Oulun yliopisto.

Kaskisaari, Marja. 1995. Lesbokirja. Tampere: Vastapaino.

Kosonen, Päivi. 1996. "Subjekti". Teoksessa Avainsanat: 10 askelta feministiseen tutkimukseen, toimittaneet Anu Koivunen ja Marianne Liljeström. Tampere: Vastapaino, 179-205.

Kähkönen, Lotta. 2018. "Kehollinen kokemus, muutos ja sukupuolen moninaisuus". Teoksessa Kokemuksen tutkimus VI: Kokemuksen käsite ja käyttö, toimittaneet Jarkko Toikkanen ja Ira A.Virtanen. Rovaniemi: Lapland University Press, 130-148.

Lahti, Annukka. 2018. "Too much? Excessive sexual experiences in bisexual women's life stories". Subjectivity 11:21-39. https://doi.org/10.1057/ s41286-017-0042-x

Lahti, Annukka. 2019. Bisexuality in relationships: a queer psychosocial approach. JYU Dissertations 87, Jyväskylä: University of Jyväskylä. http://urn.fi/URN:ISBN:978-951-39-7773-3.

Lehtonen, Jukka. 2014. "Muistot ja ajallisuus. Setan nuorten toiminta muutoksessa". SQS 8:1-2, 44-57.

Morandini, James S., Alexander Blaszczynski ja Ian Dar-Nimrod. 2016. ”Who Adopts Queer and Pansexual Sexual Identities?". The Journal of Sex Research, DOI: 10.1080/00224499.2016.1249332

Paasonen, Susanna ja Sanna Spišák. 2018. "Malleable identities, leaky taxonomies: The matter of sexual flexibility". Sexualities, 21:8, 13741378. DOI: $10.1177 / 1363460718779798$
Pöysä, Jyrki. 2006. "Kilpakirjoitukset muistitietotutkimuksessa". Teoksessa Muistitietotutkimus. Metodologisia kysymyksiä, toimittaneet Outi Fingerroos, Riina Haanpää, Anne Heimo ja Ulla-Maija Peltonen. Tietolipas 214. Helsinki: Suomalaisen Kirjallisuuden seura, 221-244.

Ristikari, Maiju, Nina Suni ja Vesa Tyni. 2018. Sukupuolena ihminen. Helsinki: Tammi.

Rosenberg, Shoshana. 2017. "Coming In: Queer Narratives of Sexual Self-Discovery". Journal of Homosexuality, DOI: 10.1080/00918369.2017.1390811

Rosenberg, Tiina. 2006. L-ordet. Vart tog alla lesbiska vägen? Stockholm: Normal förlag.

Roseneil, Sasha. 2006. "The Ambivalences of Angel's 'Arrangement': A Psychosocial Lens on the Contemporary Condition of Personal Life". The Sociological Review, 54:4, 847-869. https://doi.org/10.1111/j.1467954X.2006.00674.x

Roseneil, Sasha ja Kaisa Ketokivi. 2016. "Relational Persons and Relational Processes: Developing the Notion of Relationality for the Sociology of Personal Life". Sociology, 50:1, 143-159. https://doi. org/10.1177/0038038514561295

Rossi, Leena-Maija. 2016. "Identiteetti, queer ja intersektionaalisuus". Muuttuva sukupuoli. Seksuaalisuuden, luokan ja värin politiikkaa. Helsinki: Gaudeamus, 91-107, 183-184. (Julkaistu myös Kulttuurintutkimus 25(2008)1: 29-39.)

Rossi, Leena-Maija. 2017. "Hauras, korjaava ja parantumaton queer. Katse ylpeyden, normatiivisuuden ja (uus)häpeän aikoihin”. SQS 11:1, 1-18.

Saresma, Tuija. 2010. "Kokemuksen houkutus". Teoksessa Muistitietotutkimus. Metodologisia kysymyksiä, toimittaneet Tuija Saresma, Leena-Maija Rossi ja Tuula Juvonen. Tampere: Vastapaino, 59-74.

Sedgwick, Eve Kosofsky. 1990. Epistemology of the Closet. Berkeley: University of California Press.

Sprott, Richard A. ja Bren Benoit Hadcock. 2018. "Bisexuality, pansexuality, queer identity, and kink identity”. Sexual and Relationship Therapy, 33:12, 214-232, DOI: 10.1080/14681994.2017.1347616

Suominen, Jaakko. 2016. "Helposti ja halvalla?" Teoksessa Kirjoittamalla kerrotut. Kansatieteelliset kyselyt tiedon lähteinä, toimittaneet Pirjo Korkiakangas, Pia Olsson, Helena Ruotsala ja Anna-Maria Åström. Helsinki: Ethnos,103-152.

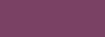

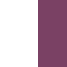

.
} 
Taavetti, Riikka.2015. ”Olissiistiä,jos eitarttismääritellä... ”Kuritonjatavallinen sateenkaarinuoruus. Nuorisotutkimusseuran/Nuorisotutkimusverkoston verkkojulkaisuja 81, Seta-julkaisuja 25. Helsinki: Nuorisotutkimusseura Nuorisotutkimusverkosto \& Seta.

Taavetti, Riikka. 2018. Queer Politics of Memory - Undisciplined Sexualities as Glimpses and Fragments in Finnish and Estonian Pasts. Helsinki: Helsingin yliopisto.

Weststrate, Nic M. ja Kate C. McLean. 2010. "The rise and fall of gay: A culturalhistorical approach to gay identity development”. Memory 18:2, 225-240. 

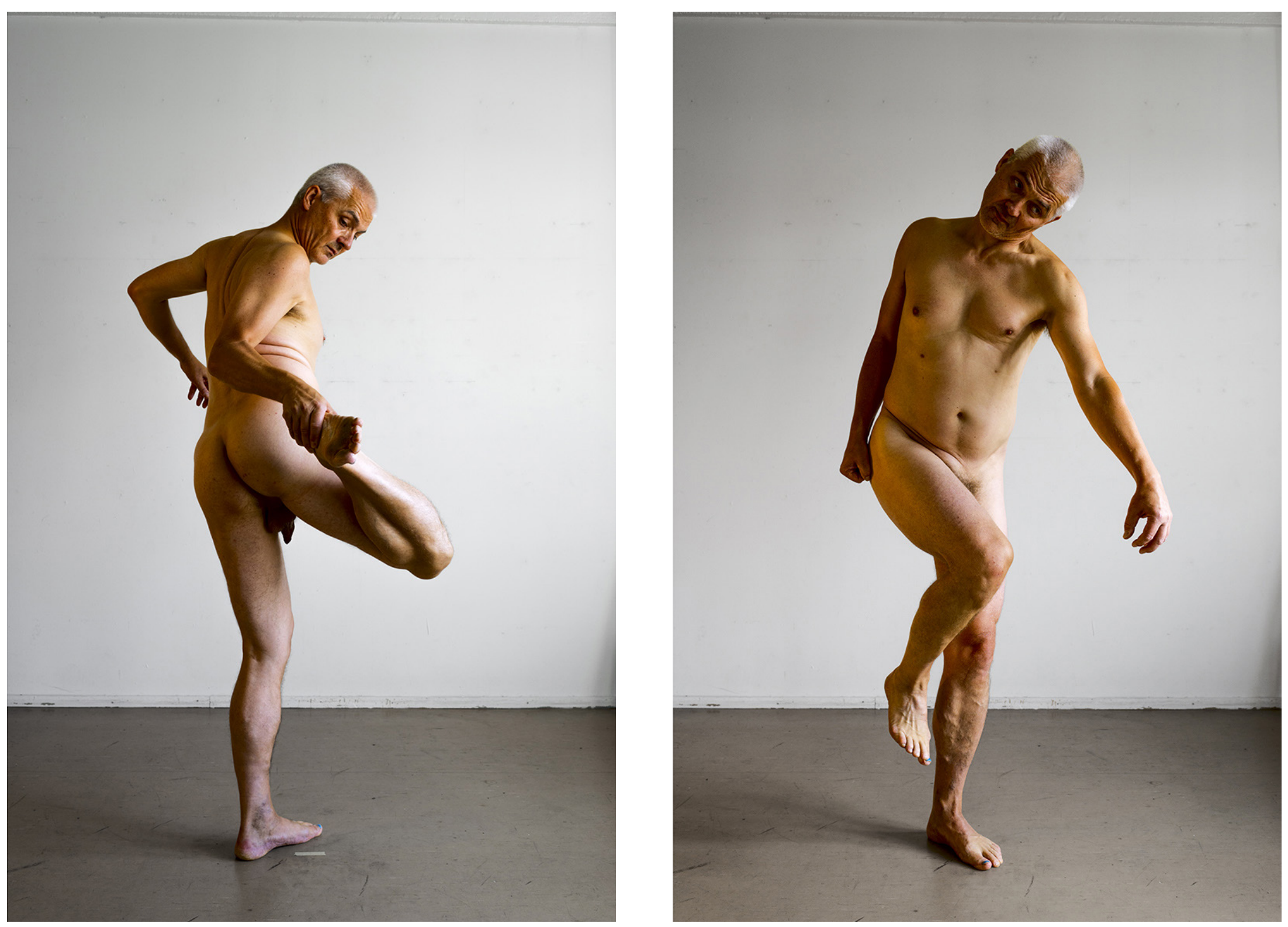

SQS

$1-2 / 2019$

22

Pervolinssi

Taidegalleria

Kari Soinio

Kari Soinio, Tanssijatar, Sankari veistoksena / 2018 (Edgar Degas, Danseuse regardant la plante de son pied droit, 1900-1910). Kari Soinio, Varjo, Sankari veistoksena / 2018 (Auguste Rodin, L'Ombre, 1902). 